ISSN 2473-8336 | jcel-pub.org

Volume 3, Issue 2

Integrating Copyright in the Curriculum: A Study of LIS Courses of Central Universities of India

Dr. Neelam Thapa

Thapa, N. (2019). Integrating Copyright in the Curriculum: A Study of LIS Courses of Central Universities of India. Journal of Copyright in Education and Librarianship, 3(2), 1-15. https://doi.org/10.17161/jcel.v3i2.6741

(C) 2019 Thapa. This open access article is distributed under a Creative Commons Attribution 4.0 License https://creativecommons.org/licenses/by/4.0/ 


\title{
Integrating Copyright in the Curriculum: A Study of LIS Courses of Central Universities of India
}

\author{
Dr. Neelam Thapa \\ Dr. Harisingh Gour (Central) University
}

Correspondence regarding this article should be addressed to Dr. Neelam Thapa, assistant professor, Dr. Harisingh Gour (Central) University, Sagar, Madhya Pradesh, India, thapaneelam05@yahoo.com.

\begin{abstract}
This research aims to study the library and information science (LIS) curriculum presently followed in the central universities of India to identify the ways in which it incorporates copyright information. The central universities offering LIS programs were identified and the curricula and syllabi of these LIS programs were downloaded from the universities' official websites. A detailed content analysis of the curricula and syllabi shows that there is no uniformity in the names of the courses taught and the course content in LIS programs of different universities. However, copyright has been included in the curriculum as part of a course in most of the universities. Based on the analysis suggestions have been made for the inclusion of copyright concepts in the curricula of LIS programs.
\end{abstract}

Keywords: Copyright, intellectual property rights, LIS education, LIS curriculum 


\section{Integrating Copyright in the Curriculum: A Study of LIS Courses of Central Universities of India}

India is fast moving toward being "Digital India." The government of India envisions India being a fully digital information society, with information technology (IT) infrastructure and internet accessibility available to all. This will ensure the integration of standalone systems and the smooth flow of information between government and citizens. Citizens will be able to openly and freely access a large amount of information, leading to better utilization of government services. ${ }^{1}$ However, since electronic information can be easily modified, it can also be misused, leading to plagiarism and copyright violations. As such, India needs to train its citizens not only to be technology savvy to access information but also to use it ethically and legally.

The Indian government has set up 40 central universities under the governance of the Ministry of Human Resource Development (MHRD) with an objective of developing these universities into world-class institutions. The aim is to not only provide world-class instructional and research facilities but also promote innovation in the teaching and learning process (Ministry of Human Resource Development, 2019).

To achieve MHRD's objective and the vision of Digital India, universities need to teach students to be info-literate and able to identify their own information needs, select appropriate sources of information, access information, and use it effectively with sound knowledge of copyright law and its implications. Libraries and library and information science (LIS) professionals need to play an important role in this process not only as information providers but also as information-literacy providers. Every user, patrons as well as librarians, has to be capable of searching for the right information and using it in an ethical and lawful way. Therefore it is imperative that copyright and related concepts be incorporated into the LIS curriculum.

\section{Library and Information Science Education in India}

LIS education in India is more than 100 years old. The first instance of LIS education is John MacFarlane's training program for the staff of the Imperial Library in 1901 (Kumar \& Sharma, 2010), founded by Sayaji Rao Gaekwad, maharaja of the princely state of Baroda. He invited William Alanson Borden to start a training program for library workers at the Central Library in Baroda in 1911. In 1915, Asa Don Dickinson established a training course at Punjab University, Lahore (now in Pakistan), which is considered to be the second library school in the world, the first being at Columbia University (Kumar \& Sharma, 2010). The birth of full-time postgraduate LIS courses in India dates back to 1931 at Madras University (Ganeshan, 2013). Later, LIS postgraduate

${ }^{1}$ The Digital India Program website provides additional information about this initiative: https://digitalindia.gov.in/content/introduction. 
courses were introduced at Andhra University (1935), Banaras Hindu University (1941), Bombay University (1944), Calcutta University (1946), and Delhi University (1948) (Ganeshan, 2013).

Presently in India education in LIS is provided at different levels, which include a bachelor's of LIS (B.Lib.I.Sc.) of one year's duration, a master's of LIS (M.Lib.I.Sc.) of one year's duration, an integrated master's of LIS (M.Lib.I.Sc.) of two years' duration, a master's of philosophy (M.Phil) of one and one-half year's duration, and a doctoral degree (Ph.D.) in LIS of three years' duration under a regular and open mode of education. ${ }^{2}$ Some universities, institutions, and library associations also offer one-year postgraduate diploma programs and six-month certificate programs in LIS.

The University Grants Commission (UGC) drafts and controls the course structure of various programs offered by the universities and colleges. The first Curriculum Development Committee (CDC) in LIS was convened by the UGC in 1990 under the chairmanship of Professor Prithvi Nath Kaula, and the second CDC in LIS was convened under the chairmanship of Dr. C. R. Karisiddappa in 2000 (Joshi, 2010). CDC 2000's report, submitted in 2001, was the basis for designing the curricula for the LIS programs. This was a big step toward bringing uniformity to the curricula of LIS programs being offered by different colleges and universities in the country. However, curriculum development is a continuous process; hence India urgently needs an organization for LIS curriculum development and accreditation of LIS courses. This has also been emphasized in studies by Mahapatra (2006), Singh and Shahid (2010), Ganeshan (2013), and Naskar (2016).

Plagiarism is an issue related to copyright. Students need to understand fair use and what can lead to copyright infringement. The UGC Minimum Standards and Procedure for Award of M.Phil./Ph.D. Degree Regulations (2016) has placed an emphasis on stopping copyright violations, evident in its notification that

The Academic Council (or its equivalent body) of the Institution shall evolve a mechanism using well developed software and gadgets to detect plagiarism and other forms of academic dishonesty. While submitting for evaluation, the dissertation/thesis shall have an undertaking from the research scholar and a certificate from the Research Supervisor attesting to the originality of the work, vouching that there is no plagiarism and that the work has not been submitted for the award of any other degree/diploma of the same Institution where the work was carried out, or to any other Institution. (UGC, 2016)

\footnotetext{
${ }^{2}$ In India, open universities have been established at the national and state levels to promote adult education at minimum cost through distance and open modes.
} 
The UGC regulation on "Promotion of Academic Integrity and Prevention of Plagiarism, 2018” also reiterates academic integrity and making students aware of plagiarism. The document clearly specifies how plagiarism can be quantified and also what penalty would be administered based on the amount of plagiarism. This helps students understand how much information they can use and quote and what would go beyond fair use and lead to copyright infringement and penalty.

\section{Copyright in Library and Information Science Curricula}

In India copyright law is governed by the Indian Copyright Act of 1957. There have been amendments to the act in 1994, 1999, and 2012 in response to technological advances. The Copyright (Amendment) Act of 1994 addressed "communication to public" and "computer programs." The 1999 amendments went further and made Indian copyright law fully compatible with Trade-Related Aspects of Intellectual Property Rights (TRIPS) Agreement, and the 2012 amendments addressed the challenges posed by the internet (Rafiqi \& Bhat, 2013).

Because libraries and information centers are facilitators of the flow of information it is imperative that library professionals be aware of copyright law to help protect the rights of the author/creator and allow easy access to information for academic and research purpose (e.g., promoting appropriate applications of fair use). Librarians are also required to impart information-literacy skills to their users and teach them to use information in an ethically and legally correct manner; for this they themselves have to be aware of copyright laws and related aspects. Librarians also have an important role in the long-term preservation of information. India has a long and diverse cultural heritage that needs to be preserved, and the Indian government has begun many initiatives in this direction-such as the National Mission for Manuscripts and Traditional Knowledge Digital Library-that are working toward long-time preservation of indigenous knowledge. LIS professionals will have to be well aware of copyright and related issues pertaining to communication and the long-term preservation of indigenous knowledge found in various forms. Given all of these factors, it is essential that copyright and related concepts be included in the LIS curriculum.

The UGC Model Curriculum, Library and Information Science (2001), which is a curriculum prepared by the UGC that universities can use as a model to develop curricula for their LIS programs, also has provisions for the inclusion of copyright information in the LIS curriculum. For example, copyright fundamentals and related concepts are suggested for inclusion in the course "Foundations of Library and Information Science"; Intellectual Property Right Acts, which include both industry-related rights (e.g., trademarks, geographical indicators, patents, etc.) and copyright, are suggested to be taught in the course "Information and Communication." 


\section{Methodology}

This research aims to study LIS curricula currently being followed in the central universities of India to find out the extent that copyright and related concepts are incorporated into it. The official websites of the 40 central universities of India set up by the MHRD were scanned to identify those institutions offering LIS programs. The curricula and the syllabi from the academic session 2016-2017 of the courses taught in the LIS programs were downloaded from the official websites of these central universities. The content of these syllabi was thoroughly studied to identify the extent of inclusion of copyright and related concepts based on the presence of the following keyterms in the syllabi: IPR, copyright, industrial rights, Copyright Act of India, intellectual freedom, fair use of information, censorship of information, plagiarism, copyright related to digital documents, and licensing. The keyterms were selected based on the UGC Model Curriculum for LIS and UGC regulations. Keeping in mind the growth of digital libraries in India and the amendments that have accordingly been made in the Copyright Act of India, copyright related to digital documents and licensing were also included as keyterms. The data was then analyzed to draw inferences and give recommendations.

\section{Data Analysis}

The official websites of 40 central universities were studied to identify the universities offering LIS programs. Out of 40 central universities in India only 16 (40\%) offer LIS Programs (Table 1).

\begin{tabular}{|c|c|}
\hline LIS Programs & Number of Central Universities \\
\hline Offered & $16(40 \%)$ \\
\hline Not offered & $24(60 \%)$ \\
\hline
\end{tabular}

Table 1. LIS programs in central universities

The appendix lists these 16 universities.

Table 2 shows the different types of LIS programs offered by these central universities.

\begin{tabular}{|l|c|}
\hline LIS Programs & Number of Central Universities \\
\hline B.Lib.I.Sc.(one year) & $7(43.75 \%)$ \\
\hline M.Lib.I.Sc. (one year) & $5(31.25 \%)$ \\
\hline Integrated M.Lib.I.Sc. (two years) & $9(56.25 \%)$ \\
\hline M.Phil. & $3(18.75 \%)$ \\
\hline Ph.D. & $14(87.50 \%)$ \\
\hline
\end{tabular}




\begin{tabular}{|l|c|}
\hline B.A. (three years) & $1(6.25 \%)$ \\
\hline $\begin{array}{l}\text { B.Lib.I.Sc./M.Lib.I.Sc. } \\
\text { (five-year integrated program) }\end{array}$ & $1(6.25 \%)$ \\
\hline $\begin{array}{l}\text { Postgraduate Diploma in Library } \\
\text { Automation and Networking } \\
\text { (PGDLAN) }\end{array}$ & $2(12.50 \%)$ \\
\hline
\end{tabular}

Table 2. Type of LIS programs in central universities

In India universities are autonomous bodies, and each university offers a different number of courses for their respective LIS programs. The curriculum of each LIS program was studied to understand the objective and structure of the LIS program (i.e., the number of core and elective courses). Then the detailed syllabus of each core and elective course was studied to find out whether copyright and related concepts were included in it.

\begin{tabular}{|l|c|c|c|}
\cline { 1 - 3 } \multicolumn{1}{|c}{ Copyright in Curricula } & \multicolumn{2}{c}{ In Number of Universities } & \multicolumn{1}{c|}{ Total } \\
\cline { 1 - 3 } & Included & Not Included & \\
\hline B.Lib.I.Sc. (one year) & $3(42.86 \%)$ & $4(57.14 \%)$ & $7(100 \%)$ \\
\hline M.Lib.I.Sc. (one year) & $2(40 \%)$ & $3(60 \%)$ & $5(100 \%)$ \\
\hline $\begin{array}{l}\text { Integrated M.Lib.I.Sc. (two } \\
\text { years) }\end{array}$ & $8(88.89 \%)$ & $1(11.11 \%)$ & $9(100 \%)$ \\
\hline M.Phil. & $1(33.33 \%)$ & $2(66.67 \%)$ & $3(100 \%)$ \\
\hline Ph.D. & $5(35.71 \%)$ & $9(64.29 \%)$ & $14(100 \%)$ \\
\hline B.A. (three years) & $0(0 \%)$ & $1(100 \%)$ & $1(100 \%)$ \\
\hline $\begin{array}{l}\text { Integrated } \\
\text { B.Lib.I.Sc./M.Lib.I.Sc. } \\
\text { (five years) }\end{array}$ & $0(0 \%)$ & $1(100 \%)$ & $1(100 \%)$ \\
\hline PGDLAN & $0(0 \%)$ & $2(100 \%)$ & $2(100 \%)$ \\
\hline
\end{tabular}

Table 3. Copyright in LIS curricula

Table 3 shows that copyright and related concepts are being taught at bachelor (B.Lib.I.Sc.), master (M.Lib.I.Sc.), and Ph.D. levels. Yet it is imperative to know whether the concepts are being taught as separate from or part of a core course or elective course because if it is taught as a core course then all the LIS students will have knowledge of copyright and related concepts. If it is taught as separate from or part of an elective course only the students who opt for that particular course will have knowledge of copyright and related concepts. Keeping this in mind, further analysis of course content was done to find out whether copyright and related concepts were included in the core courses or in the elective courses of the various LIS programs (Table 4). 


\begin{tabular}{|c|c|c|c|c|c|c|}
\hline \multirow{3}{*}{\multicolumn{2}{|c|}{ Copyright in Curricula }} & \multicolumn{5}{|c|}{ Included in Number of Universities as: } \\
\hline & & \multicolumn{2}{|c|}{ Part of a Course/Paper } & \multicolumn{3}{|c|}{ A Separate Course } \\
\hline & & Core Course & $\begin{array}{c}\text { Electiv } \\
\text { Cours }\end{array}$ & & $\begin{array}{l}\text { Core } \\
\text { Course }\end{array}$ & $\begin{array}{c}\text { Elective } \\
\text { Course }\end{array}$ \\
\hline \multicolumn{2}{|c|}{ B.Lib.I.Sc. (one year) } & 3 & - & & - & - \\
\hline \multicolumn{2}{|c|}{ M.Lib.I.Sc. (one year) } & 2 & 1 & & - & - \\
\hline \multirow{2}{*}{$\begin{array}{l}\text { Integrated } \\
\text { M.Lib.I.Sc. } \\
\text { (two years) }\end{array}$} & $\begin{array}{l}\text { I, II } \\
\text { Semester }\end{array}$ & $\begin{array}{c}6 \\
\text { (Semester I) }\end{array}$ & 3 (Semest & (II) & - & - \\
\hline & $\begin{array}{l}\text { III, IV } \\
\text { Semester }\end{array}$ & $\begin{array}{c}2 \\
\text { (Semester III) } \\
1 \\
\text { (Semester IV) }\end{array}$ & $\begin{array}{c}3 \\
\text { (Semester }\end{array}$ & & - & $\begin{array}{c}1 \\
\text { (Semester III) }\end{array}$ \\
\hline \multicolumn{2}{|l|}{ M.Phil. } & 1 & - & & - & - \\
\hline \multicolumn{2}{|l|}{ Ph.D. } & 5 & - & & - & - \\
\hline
\end{tabular}

Table 4. Copyright in LIS curricula

Table 4 shows that copyright and related issues are included in the core courses of LIS programs of all the central universities that have integrated it in their curricula. As part of a core course, copyright and related concepts are being taught to all the LIS students in India. It is also included as part of one elective course of M.Lib.I.Sc. (one-year) program and six elective courses in Integrated M.Lib.I.Sc. (two-year) program. One central university has a separate elective course called "Intellectual Property Right and Copyright" in their Integrated M.Lib.I.Sc. (two-year) program. One university offers a "Post Graduate Diploma Course on Intellectual Property Right" through a distance mode.

Analysis of the syllabi of the LIS programs, as shown in Table 3 and 4, reveals that copyright and related concepts are addressed at the bachelor (B.Lib.I.Sc.; one-year), master (M.Lib.I.Sc.; one-year), and Integrated M.Lib.I.Sc. (two-year) LIS programs. Because the universities are following different curricula and have a different number of courses with different names and syllabi, the syllabi of courses of these LIS programs were studied to identify the core courses in which copyright and related concepts were incorporated. Analysis shows that copyright and related concepts are included in different core courses by different universities. These courses were categorized under broad subject headings based on the content of their syllabi (i.e., LIS Fundamentals, Information Communication, and Digital Libraries). See Table 5. 


\begin{tabular}{|c|c|c|c|c|c|c|c|c|}
\hline \multirow[t]{3}{*}{ Name of Course } & \multicolumn{6}{|l|}{ Part of: } & \multirow{3}{*}{$\begin{array}{l}\text { Included in } \\
\text { Number of } \\
\text { Universities }\end{array}$} & \multirow{3}{*}{$\begin{array}{c}\text { Total } \\
\text { Number of } \\
\text { Universities }\end{array}$} \\
\hline & \multirow{2}{*}{$\begin{array}{l}\text { B.Lib.I.Sc. } \\
\text { (One Year) }\end{array}$} & \multirow{2}{*}{$\begin{array}{l}\text { M.Lib.I.Sc } \\
\text { (One Year) }\end{array}$} & \multicolumn{4}{|c|}{ M.Lib.I.Sc. (Twp Years) } & & \\
\hline & & & $\begin{array}{c}\text { I } \\
\text { Semester }\end{array}$ & $\begin{array}{c}\text { II } \\
\text { Semester }\end{array}$ & $\begin{array}{c}\text { III } \\
\text { Semester }\end{array}$ & $\begin{array}{c}\text { IV } \\
\text { Semester }\end{array}$ & & \\
\hline \multicolumn{9}{|l|}{ LIS Fundamentals } \\
\hline $\begin{array}{l}\text { Foundations of Library } \\
\text { and Information Science }\end{array}$ & 1 & - & 3 & - & - & - & 4 & \multirow[t]{4}{*}{7} \\
\hline $\begin{array}{l}\text { Fundamentals of } \\
\text { Information Science }\end{array}$ & - & - & 1 & - & - & - & 1 & \\
\hline Library and Society & 1 & - & - & - & - & - & 1 & \\
\hline Knowledge Society & & & 1 & & & & 1 & \\
\hline \multicolumn{9}{|c|}{ Information Communication } \\
\hline $\begin{array}{l}\text { Information and } \\
\text { Communication }\end{array}$ & 1 & - & - & - & - & - & 1 & \multirow[t]{4}{*}{4} \\
\hline $\begin{array}{l}\text { Library and Information, } \\
\text { Communication and } \\
\text { Society }\end{array}$ & - & - & 1 & - & - & - & 1 & \\
\hline $\begin{array}{l}\text { Information Science and } \\
\text { Knowledge Management }\end{array}$ & - & 1 & - & - & - & - & 1 & \\
\hline $\begin{array}{l}\text { Knowledge, Information, } \\
\text { and Communication }\end{array}$ & - & 1 & - & - & - & - & 1 & \\
\hline \multicolumn{9}{|l|}{ Digital Libraries } \\
\hline $\begin{array}{l}\text { Web Technology and } \\
\text { Digital Library }\end{array}$ & - & - & - & - & - & 1 & 1 & \multirow[t]{2}{*}{3} \\
\hline Digital Library & - & - & - & - & 2 & - & 2 & \\
\hline
\end{tabular}

Table 5. Inclusion of copyright and related concepts in core courses 
Table 5 shows that copyright and related concepts are included in the core courses teaching LIS fundamentals by seven central universities, four include it in courses teaching information communication, and three include it in courses teaching digital library concepts.

\begin{tabular}{|c|c|c|c|c|c|c|c|}
\hline \multirow[t]{3}{*}{ Name of Course } & \multicolumn{6}{|c|}{ Part of: } & \multirow{3}{*}{$\begin{array}{c}\text { Included in } \\
\text { Number of } \\
\text { Universities }\end{array}$} \\
\hline & \multirow{2}{*}{$\begin{array}{l}\text { B.Lib.I.Sc. } \\
\text { (One Year) }\end{array}$} & \multirow{2}{*}{$\begin{array}{l}\text { M.Lib.I.Sc. } \\
\text { (One Year) }\end{array}$} & \multicolumn{4}{|c|}{ M.Lib.I.Sc. (Two Years) } & \\
\hline & & & $\begin{array}{c}\text { I } \\
\text { Semester }\end{array}$ & $\begin{array}{c}\text { II } \\
\text { Semester }\end{array}$ & $\begin{array}{c}\text { III } \\
\text { Semester }\end{array}$ & $\begin{array}{c}\text { IV } \\
\text { Semester }\end{array}$ & \\
\hline Technical Writing & - & - & - & - & - & 1 & 1 \\
\hline $\begin{array}{l}\text { Archival, Museum, and } \\
\text { Archaeological Information } \\
\text { System }\end{array}$ & - & 1 & - & - & - & - & 1 \\
\hline Information Literacy & - & - & - & 1 & - & - & 1 \\
\hline Industrial Information System & - & - & - & - & - & 1 & 1 \\
\hline $\begin{array}{l}\text { Intellectual Property Right and } \\
\text { Copyright }\end{array}$ & - & - & - & - & 1 & - & 1 \\
\hline Information and Communication & - & - & - & 1 & - & - & 1 \\
\hline $\begin{array}{l}\text { Management of E-Resource and E- } \\
\text { Publishing }\end{array}$ & - & - & - & - & - & 1 & 1 \\
\hline E-Resource Management & - & - & - & 1 & - & - & 1 \\
\hline
\end{tabular}

Table 6. Inclusion of copyright and related concepts in elective courses 
The curricula of LIS programs were analyzed to identify the elective courses in which copyright concepts were included. The data found in Table 6 shows that there is no elective course in any university under the scope of this study that includes copyright in a B.Lib.I.Sc. (one-year) program, and only one university has included copyright in an elective course in an M.Lib.I.Sc. (one-year) program. However, copyright has been included in seven different elective courses in Integrated M.Lib.I.Sc. (two-year) program.

The syllabus of each course was studied to assess the inclusion of different topics on copyright in the B.Lib.I.Sc. and M.Lib.I.Sc. programs.

\begin{tabular}{|c|c|c|c|c|c|c|}
\hline \multirow{3}{*}{$\begin{array}{l}\text { Topics on } \\
\text { Copyright }\end{array}$} & \multicolumn{6}{|c|}{ Included in the Curriculum by Number of Universities in: } \\
\hline & \multirow{2}{*}{$\begin{array}{l}\text { B.Lib.I.Sc. } \\
\text { (One Year) }\end{array}$} & \multirow{2}{*}{$\begin{array}{l}\text { M.Lib.I.Sc. } \\
\text { (One Year) }\end{array}$} & \multicolumn{4}{|c|}{ Integrated M.Lib.I.Sc. (Two Years) } \\
\hline & & & $\begin{array}{c}\text { I } \\
\text { Semester }\end{array}$ & $\begin{array}{c}\text { II } \\
\text { Semester }\end{array}$ & $\begin{array}{c}\text { III } \\
\text { Semester }\end{array}$ & $\begin{array}{c}\text { IV } \\
\text { Semester }\end{array}$ \\
\hline $\begin{array}{l}\text { IPR: } \\
\text { Introduction }\end{array}$ & 3 & 2 & 5 & 1 & 1 & 1 \\
\hline $\begin{array}{l}\text { Copyright: } \\
\text { Introduction }\end{array}$ & 3 & 2 & 5 & 1 & 1 & - \\
\hline $\begin{array}{l}\text { Industrial } \\
\text { Right }\end{array}$ & - & 1 & 1 & - & 1 & 1 \\
\hline $\begin{array}{l}\text { Copyright Act } \\
\text { (of India) }\end{array}$ & 2 & 1 & 5 & 1 & 1 & - \\
\hline $\begin{array}{l}\text { Concept of } \\
\text { Freedom }\end{array}$ & - & 2 & 1 & - & - & - \\
\hline $\begin{array}{l}\text { Concept of } \\
\text { Censorship }\end{array}$ & - & 2 & 1 & 1 & - & - \\
\hline $\begin{array}{l}\text { Concept of Fair } \\
\text { Use }\end{array}$ & - & 2 & 1 & 1 & - & - \\
\hline Licensing & - & - & - & - & 1 & - \\
\hline Plagiarism & - & - & - & 1 & - & - \\
\hline $\begin{array}{l}\text { E-documents } \\
\text { and Copyright }\end{array}$ & - & - & - & 1 & 5 & 1 \\
\hline
\end{tabular}

Table 7. Topics on copyright and related concepts included in the curriculum

It is evident from Table 7 that a basic introduction to Intellectual Property Right (IPR) and copyright as well as knowledge about the Copyright Act of India is provided in B.Lib.I.Sc. and M.Lib.I.Sc. courses by all the central universities that have included it in their curricula. 
Out of nine central universities, seven (77.78\%) include copyright issues pertaining to e-documents in their Integrated M.Lib.I.Sc. (two year) programs. However, licensing and plagiarism is included by only one (11.11\%) central university.

\section{Discussion and Recommendation}

LIS education in India is more than 100 years old. However, the data shows it is taught in only 16 (40\%) of its 40 central universities. This demonstrates that LIS is not a popular subject and that its significance is not being realized by the government even though we are living in an information age and the Indian government envisions a "Digital India." So, first and foremost, the LIS profession needs to be promoted and LIS education introduced in all the central universities.

Second, all the central universities have courses with different names and course content in different LIS programs. This could have been avoided if there were a body/organization for accreditation of LIS courses. Additionally, the CDC Report 2001 is now 16 years old and much has changed in India since then. India is moving toward being Digital India and in accordance the libraries have also changed from traditional libraries to hybrid and digital libraries. Laws related to IPR and copyright have also been amended accordingly. As such, there is a dire need to constitute a new CDC to draft a curriculum according to present needs.

In India, central universities offer either B.Lib.I.Sc. (one-year) programs and M.Lib.I.Sc. (one-year) programs or Integrated M.Lib.I.Sc. (two-year) programs. Table 3 shows that copyright and related concepts are included by some central universities in their B.Lib.I.Sc. (one-year) programs and by some central universities in their M.Lib.I.Sc. (one-year) programs. The table also shows that copyright is included by $88.89 \%$ central universities offering Integrated M.Lib.I.Sc. (two-year) programs. Table 4 also shows that copyright and related concepts are included in core courses by a large number of universities so that all students learn about them. This shows that copyright is given importance and is a mandatory part of LIS education at bachelor and master degree programs. Copyright and IPR concepts are included in core courses related to LIS fundamentals and information communication in 11 out of 14 universities, and copyright related to the digital environment is included in the core courses related to digital libraries by three universities. It is also included in various elective courses. This shows a lack of uniformity and could lead to redundancy. Copyright fundamentals and the Copyright Act are included by most of the universities under the scope of this study, but copyright in a digital environment, plagiarism, and licensing find minimal representation, as seen from Table 7.

It is recommended that information literacy should be included as a core course in the second semester of B.Lib.I.Sc. (one-year) program and Integrated M.Lib.I.Sc. (twoyear) program, and basics of copyright and related concepts should mandatory inclusions. 
This will avoid repeating the same content in various courses, and its inclusion in a core course will ensure that all LIS students are aware of copyright and related concepts. It needs to be introduced at this level because many students in India begin a job after receiving their B.Lib.I.Sc., so it is imperative that they know about copyright and its related concepts. It should be taken up more extensively in the postgraduate level (i.e., M.Lib.I.Sc. [one-year] program and the second year of the Integrated M.Lib.I.Sc. [twoyear] program). Topics related to Copyright Acts in India and the role of libraries should be extensively dealt with in the course. There should be a focus on copyright issues pertaining to the digital environment, plagiarism, and licensing. This will ensure that all LIS graduates are well aware of copyright concepts and its implications in libraries.

\section{Conclusion}

Libraries in India are changing quickly to keep pace with the developing digital environment. New digital libraries are being established and traditional libraries are being transformed into digital libraries. This is an immediate need because digital libraries have numerous benefits, but at the same time it has raised some issues, and copyright is one of the biggest (Khan \& Makhdumi, 2008; Aswath \& Reddy, 2012). The LIS curriculum has to be revamped to keep the changing environment and its needs in mind. Not only information and communication technology skills but also copyright need to be mandatory in the LIS curriculum. There is a need to manage and use information efficiently, ethically, and legally. A mandatory course on information literacy, with copyright and related issues as major components, in the LIS programs would help in addressing the above issues and also bring uniformity and reduce redundancy. We need to produce LIS professionals who are proficient enough to manage digital libraries and address the various issues to adapt, survive, and be a productive part of our country's Digital India vision. 


\section{References}

Aswath, L., \& Reddy, A. N. M. (2012). Copyright law and the academic libraries: A perspective. Trends in Information Management, 8(2), 111-122.

Copyright (Amendment) Act. (1994).

bhttp://copyright.gov.in/Documents/Notification/Copyright Amendment 1994.p $\underline{\mathrm{df}}$

Ganesan, A. (2013). Education in library and information science in India: Current trends. In J. K. Vijayakumar \& P. Pichappan (Eds.), Rejuvenated libraries for empowered users (pp. 325-332). London: Digital Information Research

Joshi, M. K. (2010). Library and information science education in India: Some government initiatives. DESIDOC Journal of Library \& Information Technology, 30(5), 67-73 https://doi.org/10.14429/djlit.30.5.617

Khan, M. H., \& Makhdumi, G. (2008). Copyright fails in libraries in digital era. In J. Arora \& A. P. Gakhar (Eds.), From Automation to Transformation: 6th International CALIBER (pp. 402-409). Allahabad, India: University of Allahabad.

https://www.semanticscholar.org/paper/Copyright-Fails-in-Libraries-in-DigitalEra-Khan-Makhdumi/f5e07332959336b4dfbb4ed784319afea9d6f4fe

Kumar, K., \& Sharma, J. (2010). Library and information science education in India: A historical perspective. DESIDOC Journal of Library \& Information Technology, 30(5), 3-8. https://doi.org/10.14429/djlit.30.5.610

Mahapatra, G. (2006). LIS education in India: Emerging paradigms, challenges and propositions in the digital era. In C. Khoo, D. Singh, \& A. S. Chaudhury (Eds.), Proceedings of Preparing Information Professionals for Leadership in the new age: A-LIEP 2006. Nanyang, Singapore: Nanyang Technological University. http://hdl.handle.net/10150/106109

Ministry of Human Resource Development. (2019, 22 January). Central Universities [Webpage]. Retrieved from https://mhrd.gov.in/central-universities-0

Naskar, S. (2016). Duration of LIS education: Suffering. International Journal of Humanities and Social Science Invention, 5(12), 15-19. http://www.ijhssi.org/papers/v5(12)/version-2/B5120201519.pdf

Rafiqi, F. A., \& Bhat, I. H. (2013). Copyright protection in digital environment: Emerging issues. International Journal of Humanities and Social Science Invention, 2(4), 615. http://www.ijhssi.org/papers/v2(4)/version-3/B240615.pdf

Singh, J., \& Shahid, S. M. (2010). Changing needs of library and information science curricula in India. Library Philosophy and Practice, 357, 1-8 
THAPA 14

UGC Minimum Standards and Procedures for Award of M.Phil./Ph.D. Degree

Regulations, Part III, Section 4, p. 111 (2016). Retrieved from

https://www.ugc.ac.in/pdfnews/4952604 UGC-(M.PHIL.-PH.D-DEGREES)-

REGULATIONS,-2016.pdf 


\section{Appendix: List of Central Universities in India Offering LIS Programs}

1. Aligarh Muslim University

2. Assam University

3. Babasaheb Bhimrao Ambedkar University

4. Banaras Hindu University

5. Central University of Gujrat

6. Central University of Haryana

7. Central University of Himanchal Pradesh

8. Delhi University

9. Dr. Harisingh Gour Vishwavidyalaya

10. Guru Ghasidas Vishwavidyalaya

11. Indira Gandhi Open University

12. Manipur University

13. Mizoram University

14. North-Eastern Hill University

15. Pondicherry University

16. Tripura University 